\title{
Publisher Correction: Encryption and steganography of synthetic gene circuits
}

\author{
Oliver Purcell (10 1, Jerry Wang ${ }^{1}$, Piro Siuti ${ }^{1} \&$ Timothy K. Lu' ${ }^{1,2,3}$
}

Correction to: Nature Communications https://doi.org/10.1038/s41467-018-07144-7; published online 22 November 2018

The original version of this Article contained an error in Fig. 4. In the lower part of the three gene circuit diagrams in panel b, the flatheaded arrow linking lambdaCI to the tetR promoter incorrectly pointed to the tetR gene body. This has now been corrected in the HTML and PDF versions of this Article.

Published online: 08 January 2019

\footnotetext{
(c) (i) Open Access This article is licensed under a Creative Commons Attribution 4.0 International License, which permits use, sharing, adaptation, distribution and reproduction in any medium or format, as long as you give appropriate credit to the original author(s) and the source, provide a link to the Creative Commons license, and indicate if changes were made. The images or other third party material in this article are included in the article's Creative Commons license, unless indicated otherwise in a credit

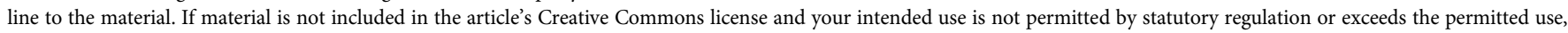
you will need to obtain permission directly from the copyright holder. To view a copy of this license, visit http://creativecommons.org/licenses/by/4.0/.
}

(C) The Author(s) 2019

\footnotetext{
${ }^{1}$ Synthetic Biology Center, Massachusetts Institute of Technology, 500 Technology Square, Cambridge, MA 02139, USA. ${ }^{2}$ Department of Biological Engineering, Massachusetts Institute of Technology, 77 Massachusetts Avenue, Cambridge, MA 02139, USA. ${ }^{3}$ Research Laboratory of Electronics, Department of Electrical Engineering and Computer Science, Massachusetts Institute of Technology, 77 Massachusetts Avenue, Cambridge, MA 02139, USA. Correspondence and requests for materials should be addressed to T.K.L. (email: timlu@mit.edu)
} 